This is a revised personal version of the text of the final journal article, which is made available for scholarly purposes only, in accordance with the journal's author permissions. The full citation is:

Sonia Heaven, John Milledge, Yue Zhang, Comments on 'Anaerobic digestion of microalgae as a necessary step to make microalgal biodiesel sustainable', Biotechnology Advances, Volume 29, Issue 1, January-February 2011, Pages 164167, ISSN 0734-9750

doi 10.1016/j.biotechadv.2010.10.005.

(http://www.sciencedirect.com/science/article/pii/S0734975010001400)

\title{
Comments on 'Anaerobic digestion of microalgae as a necessary step to make microalgal biodiesel sustainable'
}

Sonia Heaven, John Milledge and Yue Zhang

School of Civil Engineering and the Environment, University of Southampton, UK

The potential of algal biomass as a source of liquid and gaseous biofuels is a highly topical theme, and the recent review paper by Sialve et al. (2009) makes a valuable contribution towards rational assessment of the processes involved. There are, however, a number of issues concerning the results and conclusions given in the paper: these include the biomass energy values, which in some cases are unusually high; and the apparent production of more energy from processed biomass than is present in the original material. These points are important as they may affect the interpretation of the overall process feasibility.

One issue concerns the empirical formula chosen for algal protein, and the consequences of this for predicted values of methane and ammonia production. The paper adopts the formula $\mathrm{C}_{6.0} \mathrm{H}_{13.1} \mathrm{O}_{1} \mathrm{~N}_{0.6}$. This differs significantly from typical literature values for protein such as the $\mathrm{C}_{2.5} \mathrm{H}_{3.5} \mathrm{O}_{1} \mathrm{~N}_{0.5}$ suggested by Angelidaki and Sanders (2004), who provide the corresponding average formulas for lipid and carbohydrate used by Sialve et al. (2009). Sialve et al. (2009) state that the formula chosen for algal protein is based on the typical amino acid composition of Chlorella vulgaris as given by Becker (2007); but recalculation using this data shows that a better value would be $\mathrm{C}_{1.9} \mathrm{H}_{3.8} \mathrm{O}_{1} \mathrm{~N}_{0.5}$ (Table 1). Becker (2007) also gives amino acid data for several other algal species, and the calculated empirical formulae for these are very similar to this corrected value for C. vulgaris (Table 1 ).

In their paper Sialve et al. (2009) quote literature values for the biochemical composition of several algal species, and use the Buswell equation (Symons and Buswell, 1933) to determine the theoretical methane yield from anaerobic digestion of the biomass. Calculation of biomass methane yields and energy values is not completely straightforward as the compositional data are in ranges, and in many cases the proportions of protein, lipid and carbohydrate do not add up to 100\%: for Chlorella pyrenoidosa, for example, the total is only $85 \%$. One reason for this in the present case is because data in the original sources are given on a dry matter or total solids (TS) basis. The resulting specific methane yields should therefore also be quoted on a TS basis, rather than on a volatile solids (VS) basis as in Sialve et al. (2009).

Where compositional data is presented as a range, a number of approaches are possible for estimating the theoretical methane yield. One is to choose the lowest and highest percentages of each constituent and calculate the minimum and maximum methane yields respectively by ratio from the theoretical values for lipid, protein and carbohydrate, as is done by Sialve et al. (2009). Alternatively a maximum methane yield could be obtained by 
taking the minimum values for protein and carbohydrate and the maximum for lipid, which has the highest methane potential. Similar approaches maximising other constituents could be used to give intermediate estimates.

Table 2 shows the proportions of protein, lipid and carbohydrate in algal biomass given in Sialve et al. (2009) and the associated theoretical methane yields. Most of the methane yields suggested by Sialve et al. (2009) on a VS basis show good numerical agreement with values calculated on a TS basis, but the value for $C$. pyrenoidosa appears to be an error. If the theoretical specific methane yields are recalculated using the revised protein formula from Table 1, however, the values are considerably reduced and are much closer to those obtained in batch and semi-continuous trials, such as the 0.32 and $0.45 \mathrm{I} \mathrm{CH}_{4} \mathrm{~g}^{-1} \mathrm{VS}$ for Spirulina and Dunaliella respectively quoted in Sialve et al. (2009). Table 2 also gives an 'average' empirical formula for the algal biomass: interestingly, with the revised protein formula this is very close to the $\mathrm{C}_{2.08} \mathrm{H}_{3.81} \mathrm{O}_{1} \mathrm{~N}_{0.2} \mathrm{P}_{0.02}$ suggested by Grobbelaar (2004) and reported in Sialve et al. (2009). These points all support the view that the revised protein formula provides a more typical representation of the algal biomass composition, and therefore of its energy potential. The theoretical specific methane yields suggested by Sialve et al. (2009) are up to 1.5 times greater than those calculated using the revised protein formula on a VS basis, and 1.7 times greater than those on a TS basis.

The biomass composition for Spirulina platensis given in Sialve et al. (2009) is from Becker (2007) rather than the source to which it is attributed (Becker, 2004); and a factor of 8 is missing from the denominator of the equation for specific methane yield (Equation 2).

Table 3 shows calorific values for algal biomass and its products (lipid, and methane from anaerobically digested residues) for three species grown in normal and low-nitrogen conditions, based on data from IIIman et al. (2000) as reported in Sialve et al. (2009). Values are shown for measured CV; CV of the theoretical methane yield calculated on a percentage composition basis and assuming a conversion of $35.6 \mathrm{MJ} \mathrm{m}^{-3} \mathrm{CH}_{4}$ as in Sialve et al. (2009); and CV calculated from the empirical formula for the biomass using the following version of the Du Long equation (IFRS, 2004).

Higher heat value $\left(\mathrm{MJ} \mathrm{kg}^{-1} \mathrm{VS}\right)=(34.1 \mathrm{C}+102 \mathrm{H}+6.3 \mathrm{~N}+19.1 \mathrm{~S}-9.85 \mathrm{O}) / 100$

where $\mathrm{C}, \mathrm{H}, \mathrm{N}, \mathrm{S}$ and $\mathrm{O}$ are the carbon, hydrogen, nitrogen, sulphur and oxygen in the biomass expressed as \% VS; in the absence of values for sulphur this component is taken as zero. The calculated CVs based on the theoretical methane yield for the revised protein formula show very good agreement with the measured values. Using the original protein formula, however, the calculated CV is up to 1.3 times higher than the measured values, again suggesting that this version leads to artificially high energy yields. For comparison, the CV calculated using the above version of the Du Long equation is slightly higher than the measured values, but in all but one case is lower than the CV based on the calculated methane yield using the original protein formula. It should be noted that for the algal biomass in Table 3 the total for protein, lipid and carbohydrate in each case is very close to $100 \%$, meaning that there is little difference between the values for methane yield based on percentage composition or empirical formula, and between the CV on a TS or VS basis.

On the basis of their results, Sialve et al. (2009) consider the energetic content of microalgae according to two scenarios, one assuming anaerobic digestion of the whole algal biomass and the other lipid extraction with anaerobic digestion of the residues. The energy values calculated for each component on a MJ kg ${ }^{-1} \mathrm{VS}$ basis are consistent with the previous results, but an overall energy yield for the lipid and residual fraction is then obtained by adding these components together. This is misleading, since one $\mathrm{kg}$ of algal biomass when separated into lipid and residue will give only a fraction of a $\mathrm{kg}$ of each: to obtain the energy yield from a given quantity of material (or from the algal production expected from a given 
area, for example), a mass balance approach is needed. According to Sialve et al. (2009) the total energy available in $\mathrm{MJ} \mathrm{kg}^{-1} \mathrm{VS}$ from separating the lipid and residual components is $110-153 \%$ of the value in the unseparated biomass. If these total energy yields for separated products are compared with those calculated using the revised protein formula or with the actual measured calorific value, the range of suggested values is $128-175 \%$ of the maximum possible energy yield.

In the final section of their paper, Sialve et al. (2009) argue that for an algal lipid content below $40 \%$ the 'energetic added value' from separate lipid recovery is less than $21 \%$ of the recovered energy; since algal harvesting and lipid recovery are likely to require $30 \%$ of the total energy recoverable from the biomass, they suggest separate extraction is therefore not worthwhile when the lipid content is less than $40 \%$. In fact as noted above separation of the lipid and residual components does not alter the theoretically available energy and, while the lipid fraction may have a higher economic value than the methane, the net energy yield per $\mathrm{kg}$ of biomass grown will always be lower because of the energy consumed in the additional separation step. Since harvesting is an essential step in any system of algal biomass utilisation, a more useful value would be an estimate of the additional energy required for lipid extraction, as this allows comparison with the added value of a liquid fuel product on an economic basis. This is of course a simplified picture: in practice the separation process could affect the energy available from the residual biomass, e.g. by changing its anaerobic digestibility or simply due to losses of material in processing. As noted by Sialve et al. (2009), nitrogen limitation to increase the lipid content may also considerably reduce algal growth rate and biomass yield, leading to a reduction in energy yield per hectare of cultivation.

One final consequence of the choice of protein formula is its impact on the theoretical ammonia concentration in the digestate. Table 4 shows the values calculated using the original and revised protein formulas, expressed as total ammonia nitrogen in $\mathrm{mg} \mathrm{NH}_{3}-\mathrm{N} \mathrm{g}^{-1}$ VS as is conventional for anaerobic digestion studies. Apart from an error for Euglena gracilis and a misprint in the maximum value for Scenedesmus obliquus, there is good agreement between the values in Sialve et al. (2009) and those calculated using the original protein formula and percentages. It can be seen, however, that while many of the values obtained using the original formula are already in a range often considered inhibitory to methanogenesis, the revised formula gives values that are even higher. This is important, as these conditions are likely to present a challenge for stable digestion. According to the literature cited in Sialve et al. (2009) and elsewhere, algal biomass is not particularly easy to digest, as indicated by low specific gas yields and solids destruction. This may be helpful in terms of limiting the ammonia concentration in the digester, as undegraded biomass will not release its nitrogen: but in turn means that the process achieves a lower specific energy yield per $\mathrm{kg}$ of biomass added.

Determination of realistic values for the energy yields potentially obtainable from algal biomass is a complex problem and the paper by Sialve et al. (2009) provides valuable insights into the key issues; but the above analysis suggests that some of the conclusions with respect to the energy yields, the benefits of lipid separation and the risks of ammonia inhibition should be treated with caution.

\section{References}

Angelidaki I, Sanders W. Assessment of the anaerobic biodegradability of macro-pollutants. Rev Environ Sci Biotechnol 2004; 3:117-29.

Becker, EW. Micro-algae in human and animal nutrition. In: Richmond A, editor. Handbook of microalgal culture: biotechnology and applied phycology. Oxford: Blackwell Publishing; 2004. p. 312-51.

Becker, EW. Micro-algae as a source of protein. Biotechnol Adv. 2007;25:207-10.

Grobbelaar, JU. Algal nutrition. In: Richmond A, editor. Handbook of microalgal culture: biotechnology and applied phycology. Oxford: Blackwell Publishing; 2004. p. 97-115. 
IFRF. International Flame Research Foundation Online Combustion Handbook ISSN 16079116 (Method from Combustion File 24)

IIIman A, Scragg A, Shales S. Increase in Chlorella strains calorific values when grown in low nitrogen medium. Enzyme Microb Technol 2000;27:631-5..

Sialve B, Burnet N, Bernard O. Anaerobic digestion of microalgae as a necessary step to make microalgal biodiesel sustainable. Biotechnology Advances 2009; 27:409-416.

Symons GE, Buswell AM. The methane fermentation of carbohydrates. J. Am Chem Soc 1933;55:2028-36.

Table 1. Empirical formulas for algal protein based on weighted average amino acid composition (Becker, 2007)

\begin{tabular}{|c|c|c|c|c|c|c|c|c|}
\hline \multirow{2}{*}{$\begin{array}{l}\text { Amino } \\
\text { acid }\end{array}$} & \multirow[t]{2}{*}{ Formula } & \multirow{2}{*}{$\begin{array}{l}\text { Molecular } \\
\text { weight }\end{array}$} & \multirow{2}{*}{$\begin{array}{c}\% \text { in } \\
\text { C. vulgaris }\end{array}$} & \multicolumn{5}{|c|}{ Weighted proportion } \\
\hline & & & & $\mathrm{C}$ & $\mathrm{H}$ & 0 & $\mathrm{~N}$ & $\mathrm{~S}$ \\
\hline lle & $\mathrm{C}_{6} \mathrm{H}_{13} \mathrm{NO}_{2}$ & 131 & 3.8 & 2.09 & 0.38 & 0.93 & 0.41 & 0.00 \\
\hline Leu & $\mathrm{C}_{6} \mathrm{H}_{13} \mathrm{NO}_{2}$ & 131 & 8.8 & 4.84 & 0.87 & 2.15 & 0.94 & 0.00 \\
\hline Val & $\mathrm{C}_{5} \mathrm{H}_{11} \mathrm{NO}_{2}$ & 117 & 5.5 & 2.82 & 0.52 & 1.50 & 0.66 & 0.00 \\
\hline Lys & $\mathrm{C}_{6} \mathrm{H}_{14} \mathrm{~N}_{2} \mathrm{O}_{2}$ & 146 & 8.4 & 4.14 & 0.81 & 1.84 & 1.61 & 0.00 \\
\hline Phe & $\mathrm{C}_{9} \mathrm{H}_{11} \mathrm{NO}_{2}$ & 165 & 5.0 & 3.27 & 0.33 & 0.97 & 0.42 & 0.00 \\
\hline Tyr & $\mathrm{C}_{9} \mathrm{H}_{11} \mathrm{NO}_{3}$ & 181 & 3.4 & 2.03 & 0.21 & 0.90 & 0.26 & 0.00 \\
\hline Met & $\mathrm{C}_{5} \mathrm{H}_{11} \mathrm{NO}_{2} \mathrm{~S}$ & 149 & 2.2 & 0.89 & 0.16 & 0.47 & 0.21 & 0.47 \\
\hline Cys & $\mathrm{C}_{3} \mathrm{H}_{7} \mathrm{NO}_{2} \mathrm{~S}$ & 121 & 1.4 & 0.42 & 0.08 & 0.37 & 0.16 & 0.37 \\
\hline Try & $\mathrm{C}_{11} \mathrm{H}_{12} \mathrm{~N}_{2} \mathrm{O}_{2}$ & 204 & 2.1 & 1.36 & 0.12 & 0.33 & 0.29 & 0.00 \\
\hline Thr & $\mathrm{C}_{4} \mathrm{H}_{9} \mathrm{NO}_{3}$ & 119 & 4.8 & 1.94 & 0.36 & 1.94 & 0.56 & 0.00 \\
\hline Ala & $\mathrm{C}_{3} \mathrm{H}_{7} \mathrm{NO}_{2}$ & 89 & 7.9 & 3.20 & 0.62 & 2.84 & 1.24 & 0.00 \\
\hline Arg & $\mathrm{C}_{6} \mathrm{H}_{14} \mathrm{~N}_{4} \mathrm{O}_{2}$ & 174 & 6.4 & 2.65 & 0.51 & 1.18 & 2.06 & 0.00 \\
\hline Asp & $\mathrm{C}_{4} \mathrm{H}_{7} \mathrm{NO}_{4}$ & 133 & 9.0 & 3.25 & 0.47 & 4.33 & 0.95 & 0.00 \\
\hline Glu & $\mathrm{C}_{5} \mathrm{H}_{9} \mathrm{NO}_{4}$ & 147 & 11.6 & 4.73 & 0.71 & 5.05 & 1.10 & 0.00 \\
\hline Gly & $\mathrm{C}_{2} \mathrm{H}_{5} \mathrm{NO}_{2}$ & 75 & 5.8 & 1.86 & 0.39 & 2.47 & 1.08 & 0.00 \\
\hline $\mathrm{His}$ & $\mathrm{C}_{6} \mathrm{H}_{9} \mathrm{~N}_{3} \mathrm{O}_{2}$ & 155 & 2.0 & 0.93 & 0.12 & 0.41 & 0.54 & 0.00 \\
\hline Pro & $\mathrm{C}_{5} \mathrm{H}_{9} \mathrm{NO}_{2}$ & 115 & 4.8 & 2.50 & 0.38 & 1.34 & 0.58 & 0.00 \\
\hline Ser & $\mathrm{C}_{3} \mathrm{H}_{7} \mathrm{NO}_{3}$ & 105 & 4.1 & 1.41 & 0.27 & 1.87 & 0.55 & 0.00 \\
\hline \multirow{2}{*}{\multicolumn{2}{|c|}{$\begin{array}{l}\text { Total proportion \% } \\
\text { Composition }\end{array}$}} & - & 97.0 & 44.31 & 7.31 & 30.90 & 13.63 & 0.84 \\
\hline & & & & 3.69 & 7.31 & 1.93 & 0.97 & 0.03 \\
\hline \multirow{5}{*}{\multicolumn{2}{|c|}{ Formula $(\mathrm{O}=1)$}} & \multirow{2}{*}{\multicolumn{2}{|c|}{$\begin{array}{l}\text { C. vulgaris }{ }^{1} \\
\text { Dunaliella bardawil }^{2}\end{array}$}} & 1.91 & 3.79 & 1.00 & 0.50 & 0.01 \\
\hline & & & & 1.88 & 3.74 & 1.00 & 0.49 & 0.01 \\
\hline & & \multicolumn{2}{|c|}{ Scenedesmus obliquus ${ }^{2}$} & 1.83 & 3.68 & 1.00 & 0.50 & 0.01 \\
\hline & & \multirow{2}{*}{\multicolumn{2}{|c|}{ Arthrospira maxima ${ }^{2}$}} & 1.90 & 3.73 & 1.00 & 0.49 & 0.01 \\
\hline & & & Spirulina platensis ${ }^{2}$ & 1.87 & 3.72 & 1.00 & 0.48 & 0.01 \\
\hline
\end{tabular}

Used as revised protein formula in subsequent calculations

${ }^{2}$ Based on values from Becker (2007), calculation not shown. 
Table 2. Theoretical methane yields with original and revised protein formulas (recalculated from Sialve et al. 2009 Tables 2 and 4)

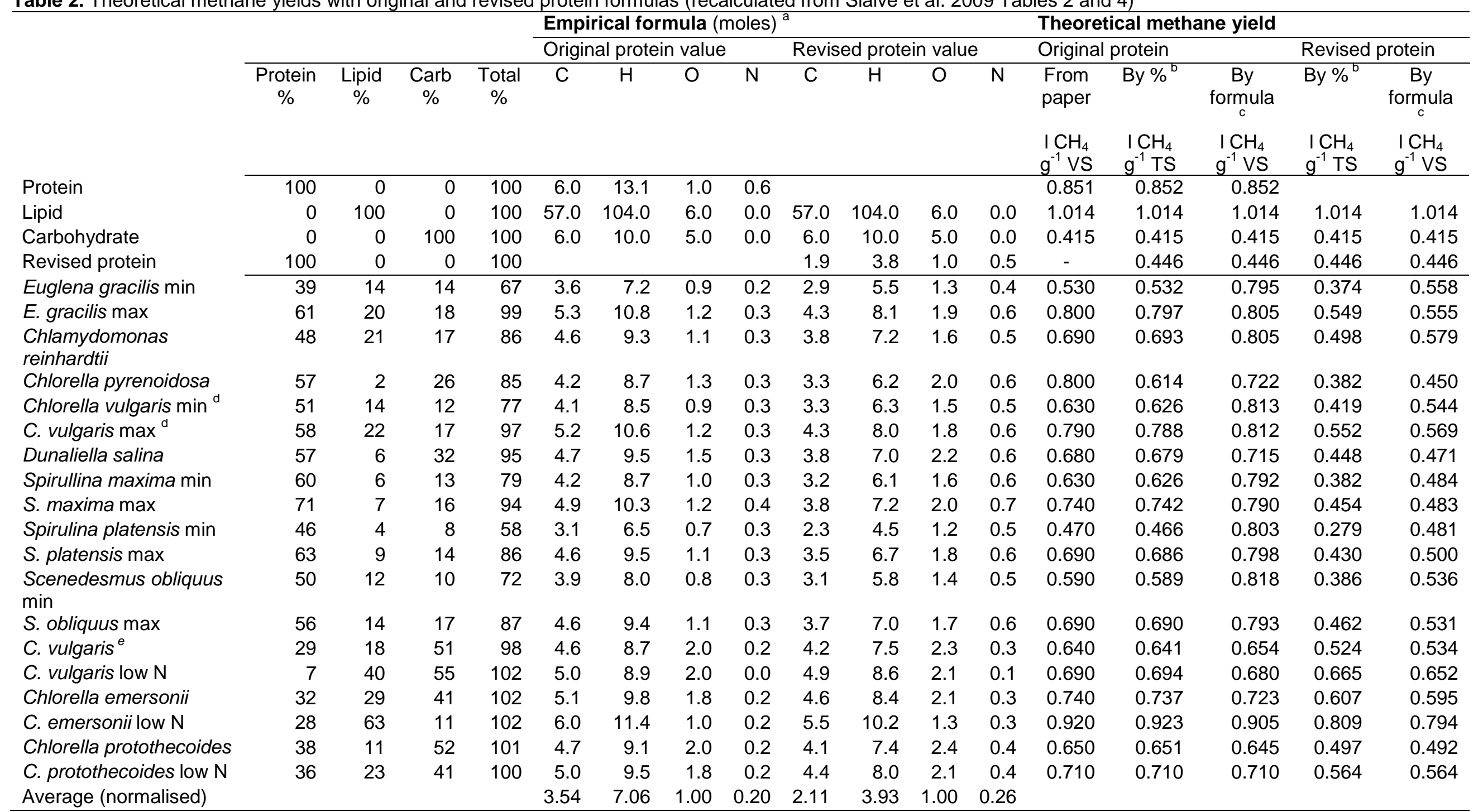

${ }^{a}$ Assuming the material is entirely composed of protein, lipid and carbohydrate, in the relative proportions shown (i.e. on a VS basis).

${ }^{b}$ Calculated from theoretical methane yields for protein, lipid and carbohydrate multiplied by the percentage of each constituent present in the material (i.e. TS basis)

${ }^{\mathrm{C}}$ Calculated from empirical formula using Buswell equation; equal to value in the previous column $\times 100 \% /$ (protein $\%+$ lipid\% + carbohydrate\%) (i.e. VS basis).

'Minimum' values are greater than 'maximum' in some cases due to the relative proportion of lipid in the values selected from the given compositional range.

${ }^{d}$ From Sialve et al. (2009) Table $2{ }^{e}$ From Sialve et al. (2009) Table 4 
Table 3. Calorific values and energetic content of microalgae with original and revised protein formulas (recalculated from Sialve et al. (2009) based on data from IIIman et al. (2000))

\begin{tabular}{|c|c|c|c|c|c|c|c|c|c|}
\hline & & Original pro & in formula & from pap & & Revised calculation an & protein forn & & \\
\hline & & Scenario 1 & Scenario & & & $\begin{array}{l}\text { Scenario } 1 \\
\text { (and Scenario } 2 \text { total) }\end{array}$ & Scenario 2 & & $\begin{array}{l}\text { Du Long } \\
\text { equation }\end{array}$ \\
\hline $\mathrm{MJ} \mathrm{kg}^{-1} \mathrm{VS}$ & Measured CV & $\mathrm{CH}_{4} \mathrm{CV}$ & $\mathrm{CH}_{4} \mathrm{CV}$ & Lipid CV & Total CV & $\mathrm{CH}_{4} \mathrm{CV}^{\mathrm{a}}$ & $\mathrm{CH}_{4} \mathrm{CV}^{\mathrm{a}}$ & Lipid CV $^{a}$ & Total CV \\
\hline C. vulgaris & 18 & 23.0 & 20.1 & 6.6 & 26.7 & 18.6 & 12.1 & 6.5 & 21.3 \\
\hline C. vulgaris low $\mathrm{N}$ & 23 & 24.9 & 17.2 & 14.7 & 32.0 & 23.7 & 9.2 & 14.4 & 25.5 \\
\hline C. emersonii & 21 & 26.4 & 22.4 & 10.7 & 33.1 & 21.6 & 11.1 & 10.5 & 24.4 \\
\hline C. emersonii low $\mathrm{N}$ & 29 & 33.1 & 27.6 & 23.2 & 50.8 & 28.8 & 6.1 & 22.7 & 31.3 \\
\hline C. protothecoides & 19 & 23.4 & 21.8 & 4.1 & 25.8 & 17.7 & 13.7 & 4.0 & 20.8 \\
\hline C. protothecoides low $\mathrm{N}$ & 24 & 25.5 & 22.2 & 8.5 & 30.7 & 20.1 & 11.8 & 8.3 & 23.0 \\
\hline
\end{tabular}

${ }^{a}$ Values calculated from methane yields based on the percentage of protein, lipid and carbohydrate and a conversion factor of $35.6 \mathrm{MJ}^{-3} \mathrm{CH}_{4}$ as used in Sialve et al. (2009). 
Table 4. Theoretical ammonia concentrations for digested algal biomass with original and revised protein formulas (recalculated from Sialve et al. (2009))

\begin{tabular}{|c|c|c|c|c|c|}
\hline & \multirow{2}{*}{$\begin{array}{r}\text { From paper }^{\mathrm{a}} \\
\mathrm{mg} \mathrm{NH}_{3}-\mathrm{N} \\
\mathrm{g}^{-1} \mathrm{VS}\end{array}$} & \multicolumn{2}{|c|}{ Original protein value } & \multicolumn{2}{|c|}{ Revised protein value } \\
\hline & & $\begin{array}{l}\text { By } \%{ }^{\mathrm{b}} \\
\mathrm{mg} \mathrm{NH}_{3}-\mathrm{N} \\
\mathrm{g}^{-1} \mathrm{TS} \\
\end{array}$ & $\begin{array}{l}\text { By formula }{ }^{\mathrm{c}} \\
\mathrm{mg} \mathrm{NH}_{3}-\mathrm{N} \mathrm{g}^{-1} \\
\mathrm{VS}^{2}\end{array}$ & 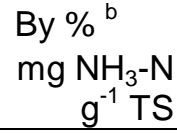 & $\begin{array}{r}\text { By formula }{ }^{\mathrm{c}} \\
\mathrm{mg} \mathrm{NH}_{3}-\mathrm{N} \\
\mathrm{g}^{-1} \text { VS } \\
\end{array}$ \\
\hline Protein & & 76.7 & 76.7 & & \\
\hline Lipid & & 0.0 & 0.0 & 0.0 & 0.0 \\
\hline Carbohydrate & & 0.0 & 0.0 & 0.0 & 0.0 \\
\hline Revised protein & & & & 141.8 & 141.8 \\
\hline E. gracilis min & 44.7 & 29.9 & 44.7 & 55.3 & 82.5 \\
\hline E. gracilis max & 69.9 & 46.8 & 47.3 & 86.5 & 87.4 \\
\hline C. reinhardtii & 36.8 & 36.8 & 42.8 & 68.1 & 79.1 \\
\hline C. pyrenoidosa & 43.7 & 43.7 & 51.4 & 80.8 & 95.1 \\
\hline C. vulgaris ${ }^{d} \min$ & 39.1 & 39.1 & 50.8 & 72.3 & 93.9 \\
\hline C. vulgaris ${ }^{d} \max$ & 44.5 & 44.5 & 45.9 & 82.2 & 84.8 \\
\hline D. salina & 43.7 & 43.7 & 46.0 & 80.8 & 85.1 \\
\hline S. maxima min & 46.0 & 46.0 & 58.3 & 85.1 & 107.7 \\
\hline S. maxima max & 54.4 & 54.5 & 57.9 & 100.7 & 107.1 \\
\hline S. platensis min & 35.2 & 35.3 & 60.8 & 65.2 & 112.5 \\
\hline S. platensis max & 48.3 & 48.3 & 56.2 & 89.3 & 103.9 \\
\hline S. obliquus min & 38.4 & 38.4 & 53.3 & 70.9 & 98.5 \\
\hline S. obliquus max & 34.8 & 43.0 & 49.4 & 79.4 & 91.3 \\
\hline C. vulgaris $^{e}$ & 22.2 & 22.2 & 22.7 & 41.1 & 42.0 \\
\hline C. vulgaris low $\mathrm{N}$ & 5.4 & 5.4 & 5.3 & 9.9 & 9.7 \\
\hline C. emersonii & 24.5 & 24.5 & 24.1 & 45.4 & 44.5 \\
\hline C. emersonii low $\mathrm{N}$ & 21.5 & 21.5 & 21.1 & 39.7 & 38.9 \\
\hline C. protothecoides & 28.4 & 29.2 & 28.9 & 53.9 & 53.3 \\
\hline C. protothecoides low $\mathrm{N}$ & 27.6 & 27.6 & 27.6 & 51.0 & 51.0 \\
\hline
\end{tabular}

${ }^{a}$ Recalculated from values expressed as ammonia but shown as N-NH $\mathrm{mg} \mathrm{g} \mathrm{VS}^{-1}$ in Sialve et al. (2009).

${ }^{\mathrm{b}}$ Calculated from the percentage of protein, lipid and carbohydrate present in the material (i.e. TS basis)

${ }^{\mathrm{C}}$ Calculated from the empirical formula; equal to the value in the previous column $\times 100 \% /$ (protein $\%+$ lipid\% + carbohydrate\%) (i.e. VS basis).

${ }^{\mathrm{d}}$ From Sialve et al. (2009) Table 2

${ }^{\text {e }}$ From Sialve et al. (2009) Table 4 